


\title{
DEVELOPING CRITICAL AND REFLECTIVE THINKING IN ART STUDIO PRACTICE THROUGH FORMATIVE PORTFOLIO MANAGEMENT: AN ANALYSIS OF PRE-SERVICE ART AND DESIGN SECONDARY SCHOOL TEACHERS
}

\author{
Attwell Mamvuto \\ University of Zimbabwe
}

\begin{abstract}
This study sought to investigate the possibility of developing critical and refleciive thinking in art and design through formative ponfolio management. The study was carried out at Hillside Teachers' College with a group of thirty-five pre-service art and aesign secondary school teachers. Data were collected qualitatively using informal conversational interviews, a semi-structured questionnaire, participant observation and analysis of documents (portfolio and studio practical work). Qualitative analysis, capturing both emic and etic perspectives, was the main mode of analysis and interpretation of data. Findings revealed that a formative porffolio is an effective mode for enbancing critical and reflective thinking provided students bave a clear conception of the object and if approached collaboratively. Visual imagery, textual information and verbalisation of thoughts were found to be critical means of showing active self-reflection during portfolio deveiopment and review. The study recommends that a formative portfolio be made part and parcel of ant leaming and every major studio assignment. Recommendations about academic examining in teachers' colleges in the discipline are made in light of findings from the study.
\end{abstract}

\section{Background}

\section{Critical and Reflective Thinking in Art and Design}

Critical and reflective thinking is a characteristic feature of visual arts education (Barret, 1990; Cho, 1999). Various art education models such as the ARTS PROPEL (Winner and Simmons, 1992), Discipline Based Art Education (DBAE) (Hamblen, 1987) and Critical Studies (Thistlewood, 1993) all emphasise the notion of critical reflection in the learning of art. Numerous research studies have shown that critical reflection improves self-awareness, conceptualisation of issues and concepts, and leads to professional growth (Eiliot, 1991; Carr and Kemmis, 1986; Hamilton, 1998; Barret, 1990; Coleman, 1996). 
The notion of experiential learning is central to the definition of reflection as espoused by Elliot (1991: 313):

[Reflection] is always a form of experiential leaming. The outcome of such learning is not knowledge stored in memory in prepositional form, but holistic understandings of particular situations which are stored in memory as case repertoires.

Reflection can, therefore, be viewed as a thoughtful process involving recollection and analysis of knowledge, 'past events, activities, thoughts, experiences and their consequential impact on the problem at hand which can lead to improvement in practical studio perfomance among art studentseverywhere.

Winner and Simmons (1992: 19) view reflection in art and design as encouraging open-mindedness:

Reflection refers to the diverse ways that students look at, think about, and write about artwork, their own art making processes, and themselves in relation to that process.

'Through critical reflection students understand themselves and grow artistically. Activities such as critique sessions, class discussions, journal entries, and guided questions have been found to help cultivate reflective attitude.

Contextial evidence of reflection include experimentations with techniques, methods and materials; inspirational visual images; plausible alternative solutions; documentation of feelings, frustrations, intentions, successes, discoveries, mistakes to avoid in future; and other general and specific comments.

In studio practice the artist performs dual functions. He is the maker or producer of an artwork and also the critic. He reflects during the production activity itself and also retrospectively as he stands back and spends time looking at, and thinking about the work in progiess. Henry Matisse a renowned Fauvist once remarked that, "At the next sitting, if I discover some weakness in the whole canvas, I use this flaw as a point of te-entry" (Guichard-Meili, 1967:31, cited in Prentice, 1995: 13). The remark emphasises the ongoing process of critical reflection during art production.

Richard Paul, cited in Stout (1995: 173), proposes 20 strategies that foster critical and reflective thought in Art and Design. 
Strategies that Foster Critical Thinking About Art

1. Employ the skills of meticulous observation, looking beyond the surface into the discovery of the richness of detail.

2. Draw inferences and form logical interpretations based on observation, reading, and other forms of communication.

3. Use the vocabulary of the discipline appropriately and precisely.

4. Transfer leaming from one situation to another.

5. Compare and contrast.

6. See and discover relationships.

7. Make informed decisions and reasonable choices.

8. Support opinions and wage arguments with credible facts, information, examples, explanations, descriptive details, quotations and incidents.

9. Distinguish between substantiated and unsubstantiated opinion, and separate relevant from irrelevant information.

10. Weigh meanings and evaluate the credibility of sources.

11. Analyse information and ideas and understand their relationship.

12. Synthesize or put ideas together to form a new idea or concept.

13. Recognise the plausibility of more than one correct answer or solution to a problem.

14. Identify fundamental problems and recognise major issues.

15. Perceive the complexity of an issue or concept.

16. Generate solutions to problems.

17. Withhold judgement or evaluation until valid and adequate evidence has been established.

18. Make evaluations based on fairly established standards.

19. Predict.

20. Revise and rethink.

Barret (1990) suggests that reflection in art involves three domains: conceptual, operational and synthetic. These are derivatives from the three primary concerns of art, namely production, perception and reflection. The conceptual domain relates to ideas, perceptions, feelings, impulses and responses. The operational domain denotes control and use of techniques, materials and media, while the synthetic domain is concerned with the dynamic interaction of art elements and principles of 
design. The three domains have a symbiotic relationship and interact with the artist and his cultural context=âs illustrated below.

\section{Figure 1: Interaction of the Three Reflection Domains and Cultural Context}

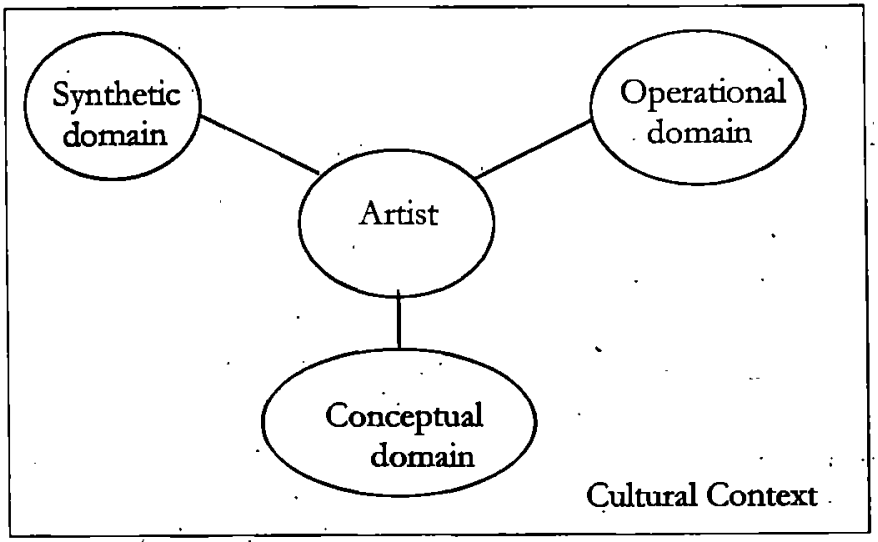

In line with Barret's domains are Perkins' (1992) forms of knowledge that students display during the process of reflection. These are content knowledge, problem solving knowledge, epistemic knowledge and inquity knowledge. Content knowledge denotes concepts and facts. Inquiry knowledge relates to how learners understand and challenge results and assumptions and construct new knowledge. This is particularly true in the visual arts where students have to generate alternative solutions to design briefs or creative problems. In epistemic knowledge; students conduct justificatery and explatratory performances. Reflexivity is evident when there is deliberate articulation of the forms of knowledge.

\section{Critical Reflection and the Formative Portfolio}

A formative portfolio has been found to be an integral vehicle in promoting reflective thinking in studio art. By definition, a portfolio is tangible documentary evidence of artistic learning and student initiative. Traditionally, a portfolio is viewed as an artefact consisting of carefully selected artworks. It is a "display of a public professional self" (Castiglione, 1996: 3). Coleman (1996: 219) defines a portfolio as "a purposeful collection of student work that tells the story of the student's efforts, progress or achievements in a given area." There has been debate as to who selects work to include in this portfolio. It is, however, generally agreed that it is the 
student's prerogative to hake the final informed choice and that teachers and peers only make recommendations (Winner \& Simmons: 1992).

In this study, a formative pottfolio has been operationalised as a document in various óptional formats where thought processes are recorded. These include procesi drafts, duds; discărọded approaches, sketches, collages, layouts, experimentations; visual and textual information. It is a purposeful and systematic collection of students ideas that demonstrate their efforts and accomplishments. In the portfolio students gather and organise materials reflecting active learning. It is also viewed as a reflective self-assessment tool. The assessment dimension of the portfolio has been explored extensively (Castiglione, 1996; Centra, 1994; Fontana, 1995 \& Shannón, 1994, cited in Cho, 1999). During the process of recording design information, students engage in reflection, self-monitoring and self-assessment. Portfolio production is usually a collaborative effort between the student and teacher, peers and in some cases parents (Paulson et al, 1991; Tiemey et al, 1991; \& Mamvuto, 2002). The data collected during the collaborative effort assists the teacher in making informed instructional decisions and reflecting critically in order to help students learri and meet their studio targets.

Verbal and non-verbal evidence of critical and reflective thinking during formative portfolio development and reviews include:

- diverse visual research,

- critical and-reflective statements using critical vocabulary,

- informed selections of plausible altematives to the same problem,

- relating methods, techniques, processes, media and material choices;

- critical stiudent generated questions and comments,

- relational analyses of background information and problem at hand.

-..asthetic responses, and

- informed oral statements or comments.

\section{Conceptualising the Problem}

I have observed that during studio practice my students are focused more on the final resolution (examinable work) and are less committed to recording of thought processes and procedures. Such documentation could be in the form of visual research images and written reflections on conceptual, operational and synthetic domain's of art (Barret, 1990). As a result, brilliant ideas worth further exploration 
and actualisation are normally left undeveloped as students settle for their initial ideas. The noted documentation mostly consisted of unstructured direct citations of visual imagery from magazines, posters, brochures and other secondary sources, and these are usuallly treated as final design solutions. Copied visual exemplars constantly show little reflection and individual input in answer to the design problem at hand. Although citations and use of exemplars are a recömmended and useful part of visual research and art learning (Stout, 1995), individual input is nonetheless required.

The tendency to value the final antwork is also demonstrated by ways in which academic exarnining in associate teachers' colleges in the subject area is conducted. 'Under the Scheme of Association, colleges have their programmes accredited by the University of Zimbabwe. Colleges apply for the university's participation in their academic matters (UZ Board of Studies ASTC/23/96) such as academic examining, curriculum development, and general programme monitoring and supervision. These procedures are meant to ensure quality maintenance and systems dȩvelopment.

Dissertation exhibitions by art and design finalist students usually consist of carefully selected best piecess of artwork for presentation and assessment. These are selected mostly with the assistance of lecturers during intemal assessment in preparation for external moderation of the examinations by the university. The works provide a summative assessment of mastered competencies. These, however, seem inadequate in demonstrating the candidates' abilities to reflect and think through artistic procedures vital for effective art leaming.

It would seem such self reflective competencies require more formative documentary procedures and general collaboration between the lecturer and student in order to assist the leamer to publicly conceptualise his/her intentions and thought processès:

\section{Purpose and Objectives of the Study.}

The principal purpose of the study was to investigate strategies to develop critical and reflective thinking in art and design students through effective portfolio management. The study also aimed at improving conceptualisation of artistic 
knowledge through methodical documentation of both visual research and textual information. The specific study objectives were to:

1. solicit students' reactions to the notion of formative portfolio development and their views with regards its implementation,

2. help students develop and effectively manage a formative portfolio,

3. asist students develop critical and reflective thinking through creative methodical documentation of research information, and

4. assist students in conceptualisation and realisation of artistic knowledge through exploring self defined themes in printmaking.

\section{Research Paradigm}

In view of these purposes and objectives of the study the researcher used an action research paradigm. The design is a self-reflective mode of inquiry into one's practice. The paradigm allows the researcher to inquire into his practice, make changes and evaluate the effects of those changes to his practice (Kemmis \& McTaggart, 1982; McKernan, 1991; Miller, 1990). Action research enhances personal understanding, improves insight into problems and raises commitment to effect appropriate changes. These advantages necessitated the use of the paradigm in this study. The study explored printmaking using a variety of methods.

\section{Participants}

Thirty-five second year finalist 2002 art and design student teachers participated in the study. The secondary teachers' college offers a two year teacher education course to post ' $A$ ' level candidates.

Although the entrance requirements are Advanced level passes in the subjects to be majored in, admission into art and design is mostly by interest and general aptitude in the visual arts. This is partly because there are few students who take Art at Advanced level (Abraham, 2002). The group under study had two students with Art at Ordinary level and one with the subject at Zimbabwe Junior Certificate (ZJC) level. The rest opted into the subject through interest and general aptitude or failure to secure places in their second subject area during registration.

The students were not given a selection test upon admission to determine their level of artistic knowledge that could help inform instructional and pedagogical strategies. 
Comprehensive selection strategies are however vital if students are to benefit from the system. Lack of releyant academic and artistic background makes it imperative that I develop in the'sțidents critical and reflective thinking capabilities.

The study was, however, based on the premise that at the last term.stage of the course; the participants had developedaesthetic, perceptual and manipulative skills to the extent that these conceptual and practical issues would not hinder effective grasp of the new concept of portfolio management.

\section{Data Collection Methods and Analysis}

Data were collected qualitatively using a semi structured questionnaire personally administered by the researcher at the end of the domain project; unstructured informal conversational interviews with students; document analyses (portfolios and final prints); and participant observation during studio practice. The methods provided means of triangulation to validate data collected. Guba and Lincoln (1989) emphasise the need to use multiple data collection methods to authenticate qualitative data. They articulate the concept of credibility, dependability, confirmability and transferability in qualitative research synonýmous to validity and reliability in quantitative research paradigm.

Qualitative analyses were used in order to accommodate the relative artistic knowledge bases of students. Some quantitative analyses were minimally employed. Both emic and etic perspectives in data analyses and interpretation were used (Marshall \& Rossman, 1999; Bogdan \& Biklen, 1992; Mouton \& Marais, 1990): Content analyses were done to determine the extent to which students manifested critical and reflective thinking. I used strategies that foster critical and reflective thinking as proposed by Richard Paul (cited in Stout, 1995). These were, however, adapted to aid analysis of visual information. Analysis involved establishing genres of data displayed in portfolios followed by qualitative analysis of how the kinds of data reflected critical and reflective thinking.

The questionnaire had "agree" and "disagree" items as well as open-ended questions. These were focused on students' conception of the portfolio, its value and its effective management. Conversational interviews were meant to enable students verbalise their thought processes. An advantage of this form of interviewing is that it is context bound and occurs spontaneously such that the 


\section{A.Mamvuto}

interviewee may tot even know that she/he is being interviewed. I did not prepare the questions in advance, but $\mathrm{I}$ had in mind general areas to be discussed such as media ưsed, methods and techniques, theme development and evaluation.

Conversational interviews and observations were simultafieously employed as students went about their studio "work.

\section{Procedure}

The following is a brief outline of the principal stages that I followed. Firstly, I had an open class discussion and exposition on the concept of formative portfolio and its effective management. Secondly, a task was set.in the area of print making. $\mathbf{A}$ range of prititing methods were introduced, discussed and demonstrated to enable students make informed selections of appropriate methods for specific designs. The following methods were discussed: collograph, serigraphy, linoleum printing, etching, blue filler method, card printing method, any combination of the above.

Below is the problem that was set and attempted individually by the students. 


\section{GROUPS: AL2 MS1 $\cdot$ AND MS2 \\ DOMAIN PROJECT \\ PRINT MAKING}

Domain projects are long term studio projects on issues central to the visual arts. They emphasise process, as well as product, encouraging students' active involvement in experimentation, research, (and) revision. They intergrate production with perception and refletion. They provide,opportunities for self and peer assessment-as well as teacher-student assessment.

Attempt an exploration of a single theme of your own choice using any four of the following printing techniques:

1. Collograph

2. Blue filler method

3. Etching

4. Linoleum printing

5. Card printing method

6. Serigraphy

7. Any combination of the above.

Your starting point is building a dossier of supporting research ideas, preparatory sketches, collages, on-spot sketches, photographs, etc, which should be appropriately documented in a personal portfolio. Written notes and comments should show personal involvement and reflection on critical issues and processes. Credit will be awarded to such a formative portfolio. The four pieces for final assessment should be professionally mounted and clearly marked.

\section{N.B. Use appropriate measurements.}

Students were asked to select and explore their individual themes in portfolios. Formal and informal consultations were held during the course of portfolio development. During the process, the student was given greater latitude and choice because as posited by Cho (1999) and Castiglione (1996), a portfolio should be personal, with no rigid criteria and procedures about its development. Guiding questions and suggestions that initiated active self reflection by the student were asked by the researcher. The main thrust was on development of perceptual and 
reflective skills and personal understandings by the student of the diverse concepts and issues involved in the portfolio process.

After portfolio development and a series of printing sessions, a semi structured questionnaire was then personally administered by the researcher. This was to ensure a $100 \%$ return rate of the instrument. Lastly, there was content analyses of the portfolios and students' final practical studio prints.

\section{Results}

\section{Excerpts on Students' Conceptions of a Formative Portfolio}

1. It is the itinery that reflects how I progress stagically towards acbieving a given solution. It bas got all the bits and pieces I use in the project. It says all about it.

2. A portfolio could be a booklet with ideas of a particularproject. It also tells bow one develops or materialises them into working solutions. You reflect on processes, findings and feolings.

3. It is a joumal where you put down your ideas of research when undertaking a project. The ideas could be written, in form of pictures or photos. Steps taken in executing the project are also bighlighted.

4. It is a designed booklet that one uses for the thumbnails for what will be designed by the artist. This is where the artist exhausts all bis artistic mind so as to come up with the best solution.

The above excerpts indicate clear understanding of the notion of formative portfolio by most students. This understanding impinges directly on implementation and development of ideas in the document. With such conceptions students are likely to approach the portfolio reflectively. The definitions identify key reflective elements such as developmental stages, documentation of ideas, processes, procedures, findings, thoughts and coming up with possible solutions. There is no format in its construction. It is, therefore, approached from an individual perspective. 


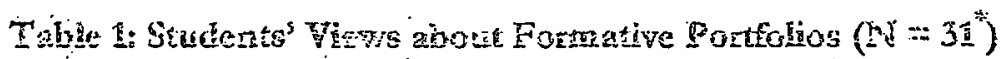

\begin{tabular}{|c|c|c|c|c|c|}
\hline \multirow{3}{*}{ Item } & \multirow{3}{*}{ 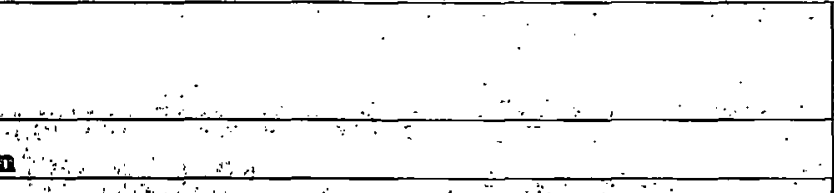 } & \multicolumn{4}{|c|}{ Responses } \\
\hline & & \multicolumn{2}{|c|}{ Agree } & \multicolumn{2}{|c|}{ Disagree } \\
\hline & & \multirow{2}{*}{ F } & \multirow{2}{*}{\begin{tabular}{|c|}
$\%$ \\
87.1 \\
\\
\end{tabular}} & \multirow{2}{*}{$\frac{F}{4}$} & \multirow{2}{*}{$\%$} \\
\hline 1. & $\begin{array}{l}\text { A portfolio is ar indispensable tool in art teaching and } \\
\text { learning }\end{array}$ & & & & \\
\hline 2 & A portfolio is time consiuming & 14 & 45.2 & 17 & 54.8 \\
\hline 3 & $\begin{array}{l}\text { Final product is more important than building ideas in a } \\
\text { portfolio }\end{array}$ & 7 & 22.6 & 24 & 77.4 \\
\hline 4 & Building ideas in a folio is more important than final product & 20 & 64.5 & 11 & 35.5 \\
\hline 5 & I would tather do without a portfolio & 4 & 12.9 & 27 & 87.1 \\
\hline 6 & $\begin{array}{l}\text { All projects should start with documentation of ideas in a } \\
\text { folio }\end{array}$ & 27 & 87.1 & 4 & 12.9 \\
\hline 7 & $\begin{array}{l}\text { Portfolios should be personal and should not be assessed or } \\
\text { evaluated }\end{array}$ & 7 & 22.6 & 24 & 77.4 \\
\hline $\begin{array}{r}8 \\
\end{array}$ & $\begin{array}{l}\text { Portfolio development should be a collaborative venture } \\
\text { between student and teacher }\end{array}$ & 29 & 93.5 & 2 & $\dot{6.5}$ \\
\hline 9 & Portfoliós develop in students critical and reflective skills & 31 & 100 & 0 & 0 \\
\hline 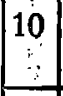 & $\begin{array}{l}\text { I clearly understand the purpose of a portfolio and how it is } \\
\text { developed }\end{array}$ & 22 & 71 & 9 & 29 \\
\hline 11 & $\begin{array}{l}\text { All artistic endeavours should be spontaneous and not be } \\
\text { planined for as in portfolios }\end{array}$ & 5 & 16.1 & 26 & 83.9 \\
\hline 12 & This is my first time to develop a portfolio & 28 & 90.3 & 3 & 9.7 \\
\hline 13 & I need more ideas and practice in portfolio development & 30 & 96.8 & 1 & 3.2 \\
\hline $\begin{array}{l}14 \\
\because \\
\end{array}$ & Ideas documented in a portfolio can be used in future & 31 & 100 & 0 & $\mathbf{0}$ \\
\hline 15 & A & 30 & 96.8 & 1 & 3.2 \\
\hline
\end{tabular}

N.B.: Four students were absent when the questionnaire was administered. 
From the above statistics, most students (87.1\%) viewed a formative portfolio as something indispensable in art teaching and learning. However, $45.2 \%$ viewed it as something that is time consuming in its implementation. $12.9 \%$ said they would rather do without a portfolio and these are supported by the $16.1 \%$ who said artistic endeavours should be spontaneous and need not be planned for in portfolios.

Some students have reservations about portfolio implementation as reflected in items $2,3,5$ and $11(45.2 \% ; 22.6 \% ; 12.9 \% ; 16.1 \%$, respectively). These statistics tend to contradict the general feeling $(96.8 \%)$ that portfolios make a student an active learner. Another contradiction is where $22.6 \%$ say portfolios are personal and should not be assessed, while (93.5\%) are of the view that portfolio development should be a collaborative venture between the lecturer and student. In this study I worked collaboratively with students in portfolio development. I did not award assessment marks to these porfolios.

Overally, students have a positive perception about a portfolio but would need to be more familiar with regards its use. This is supported by the $96.8 \%$ who need more ideas on its use. 
Tabie 2: Kinds of Data in Students' Portfolios and their Frequencies $(\mathrm{N}=35)$

\begin{tabular}{|l|r|r|}
\hline Data Type & F & $\%$ \\
\hline Textual & & \\
- Information texts & 125 & 18.5 \\
- Analytical and reflective texts & 80 & 11.9 \\
- Cut out texts & 30 & 4.4 \\
- Descriptions of processes and & 20 & 3.0 \\
techniques & & \\
Visual Imagery & 135 & 20.0 \\
- Cut out images & 120 & 17.8 \\
- Copied images & 55 & 8.1 \\
- Sketches, thumbnails, dus, etc & 20 & 3.0 \\
- Experimentations & 60 & 8.9 \\
- Referenced and adapted images & 30 & 4.4 \\
- Oiginal and unreferenced images & 0 & 0 \\
$\because$ Photographs & 0 & 0 \\
- Collages & & \\
\hline Total & 675 & 100. \\
\hline
\end{tabular}

The statistics indicate that there is more visual imagery $(62.2 \%)$ than textual information $(37.8 \%)$. However, visual data consists mainly of cut out images and copied drawings. Although these are relevant ideas, there is limited experimentation noted with those ideas. The low percentage of referenced and adapted images (8.9\%) and original and unreferenced images $(4.4 \%)$ seem to suggest some limitations in adapting the images to individual purpose and intention.

Analytical and reflective text $(11.9 \%)$ compares fairly well with informational text. Students managed to successfully describe processes and techniques they would implement in print making. From an analysis of the portfolios, it would appear students have high potential levels in critical reflective practices. Cut out images were blown up through photocopying and the resultant images were used directly as print images. The final prints looked different from the original designs due to printing processes and techniques used. 


\section{A.Mamvuto}

Figure 2: A summary of core reflective stages students went through during the course of portfolio development

\section{REFLECTION ON THE PROBLEM}

- Problem statement

- Analysis of problem

- Preliminary decision on materials and processes.

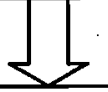

\section{RESEARCHING AND GATHERING INFORMATION}

- Collecting and collating related information

- Deciding on appropriate materials and techniques

- Preliminary sketches (brainstorming)

- Researching on various options available

- Adoption of some of the ideas

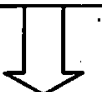

\section{DEVELOPMENT OF SELECTED ALTERNATIVE(S)}

- Choosing the best option

- Plannino before actualisation

\section{REALISATION OF SELECTED ALTERNATIVE(S)}

- Actual printing

- Adjustments and modifications during the printing process

- Consider presentation e.g. mounting

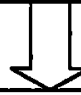

\section{EVALUATION}

- Reflection on initial problem, processes and solution

- Most students' evaluations were very brief but informative. They addressed critical issues of the whole printing process 
Variations were noted on reflection on individual problems. Most students included both written notes and visuals in problem clarification.

A variety of information, both textual and visual, was collected and reflected upon before actualisation. There was clear evidence of critical consideration of alternatives, their advantages and disadvantages before final selection of the most plausible alternatives. Although everything was planned for in the portfolio, the printing processes had lots of adjustments as unforeseen challenges were encountered. For example, oil based printing inks poised their own handling challenges which were not anticipated as this was new medium to the students. A sketched design solution was altered when cut but, for example on stone.

These: modifications, successes and failures were documented in the written evaluations. As the author reflected with the students during the printing process, critiques and review sessions, such challenges were also brought up.

\section{Researcher's Comments in Students' Portfolios Meant to Initiate Self-Reflection}

In order to promote critical and reflective thinking, I did not award marks to the portfolios. I did not want students' focus to be diverted by the notion of assessment. The idea was to be as positive as possible in the comments and suggestions. The comments below were meant to initiate critical reflection on various aspects of the portfolio.

- 'This is good documentation of ideas on the chosen theme. Background information is quite relevant although it should now inform bow you develop your chosen solution. Let's bave more of your own visuals showing processes involved, e.g. designs, layouts, techniques, colour, etc."

- "You made a good collection of relevant pictures, drawings and background information. Most drawings are suitable for further development which you should bave done through experimentation in visual form."

- "Relevant cuttings were collected. Now let's bave more of your own drawings that illustrate bow you developed some of the ideas into workable solutions."

\section{Students' Reflective Statements in Portfolios}

Reflective practice is an interactive and dialogical process. This can be inter-dialogue between two persons or intra-dialogue where the student reflects within himself. 
This cognitive covert process is, however, made accessible through graphic representations and written comments. The following excerpts demonstrate this vital on-going process of reflection during portfolio development by one student who explored a social issue of street kids.

\section{Reflecting on the Problem}

- "Recent reports by the City of Bulawayo show an increase in the number of street cbildren who bave been abandoned by their parents or dumped by their single mothers at a tender age ... the girl child on the street is exposed to an unbecoming life style ... that most of them resort to prostitution so as to get money for their living. The Edgars Club in the year 2001 published an article about bow best people could belp the street kids who are begging from the streets."

\section{Reflecting on Visual Research Imagery}

- "The lady bebind the man is also starring at the kids, ber presence in the scene is to show how modem women lack motherly qualities to offer belp. She stands aloof behind the man."

- “... the illustration is aimed at presenting the survival means of the street kids, the bin behind is the source of food for the kids, one can imagine all the filthy stuff that the street kids survive on."

\section{Reflecting on Processes and Techniques}

- 'T then proceeded to making the print, firstly by creating a background using the etching method and then proceeded to cutting out the positives of the bodies and litter bins on the stencil before sprinkling/brushing colour through the holes."

\section{Synthesis and Discussion}

Reflective thinking is a critical component in artistic development. This study was able to confirm findings by various studies (Cho, 1999; Stout, 1995; Barret, 1990; Mamvuto, 2002) on the invaluable benefits of reflection. Through reflection, one becomes aware of his/her own knowledge and cognitive strategies. As students went about reflecting on the various aspects of the portfolio such as theme, media use, techniques and approaches, using three critical means, visuals, texts and oral presentations, they were able to make accessible their cognitive processes and 


\section{Zimbabar Journal of Edicational Rescancb}

strategies. This is a vital aspect of art leaming as student artists need to publicise their artistic understandings.

A portfolio has been found to be an important aid in documenting such artistic endeavours. In the portfolio, students become problem-solvers.as they reflectively consider alternative thoughts and perspèctives through : collected information. $\because$

Complimentary to visual documentation are oral interactive processes between the teacher and student(s) "or amongst students. This dialogical process brings enlightened insights into artistic problems and procedures. These demonstrate the quality of reflective achievement as students respond sensitively to the various aspects of studiotproduction. Interpreting a visual representation (artwork) and creative use of various plastic elements of art is the domain of reflective thinking. Quality time spent in critique sessions, informal conversations and portfolio reviews assists students in studio accomplishments.

The study found that portfolio development need not be tigidly structured, but be flexible and accommodative by allowing students latitude to document their hunches and other reflective thoughts. Some students are more visually öriented and as such should be accorded that opportunity. An obvious recommendation emanating from the study is making the portfolio process a pre-requisite in all major studio tasks. This will aid gradual acquisition of teflective capabilitiēs;"especially with such students as those who participated in this study who had no prior knowledge about portfolio development.

1 found that asking developmental guiding questions is critical if reflective skills are to be developed. Questions that initiate aesthetic responses should complement supportive comments and suggestions. By the end of the day; each student should feel they have learnt something. This develops confidence and instils a deeper exploratory and inquitsitive attitude in the learner. Winner and Simmons (1992) say that-curriculat context ard classroom atmosphere should support gradual integration of reflective thinking. Teacher's questions could be based on cultural, historical, social and artistic origins or basis of the art work. This broadens students' basis for reflective analysis.

However, underlying successful implementation of the portfolio process is a clear conception of the object. A few students who had conceptual problems with the 
document and its effective implementation also had problems in demonstrating reflective skills. These are the students who relied heavily on cuttings, photocopies and other borrowed imagery.

\section{Recommendations for Assessment}

\section{Recommendation I}

One of the objectives of visual arts teaching is to promote creative and innovative thinking and development of a critical and reflective mind. However the current system of assessment in Zimbabwe teacher education colleges appears to put more emphasis on assessing the end product. The positive results from the study point at the possibility of actually assessing the thought processes. This includes docimenting one's ideas in a portfolio and administering an oral interview during dissertation exhibitions, during which sampled candidates are asked to explain their ideas as developed in the portfolio and on exhibition. An instrument specifically. designed to assess this critical and reflective capability could be made. This is then used by both the internal and external assessors. 
Table 3: A Summative Portfolio Assessment Form

\begin{tabular}{|c|c|c|c|c|c|}
\hline . & Comp & $\begin{array}{l}\text { ectiv } \\
\text { lcy } F\end{array}$ & ank & & $\begin{array}{l}\text { Asséssor's } \\
\text { Comments }\end{array}$ \\
\hline DATA TYPE & & \begin{tabular}{l|l}
12 \\
1
\end{tabular} & 3 & $\begin{array}{lll}4 & 5\end{array}$ & \\
\hline $\begin{array}{l}\text { TEXTUAL DATA e.g. } \\
\text { - Critical evaluation } \\
\text { - Reasoned judgements/interpretations } \\
\text { - Analysis and synthesis }\end{array}$ & 15 & & & & \\
\hline $\begin{array}{l}\text { VISUAL IMAGERY e.g. } \\
\text { Visual research } \\
\text { Annovative use of media, techniques, methods, } \\
\text { Analysis and synthesis of visual imagery. } \\
\text { Feeling for a style } \\
\text { Plausible altematives }\end{array}$ & 20 & & & & \\
\hline $\begin{array}{l}\text { ORAL INTERVIEW } \\
\text { Logical interpretations of artworks } \\
\text { Establishing altematives/relationships } \\
\text { Critical self-evaluations } \\
\text { Awareness of artistic processes and procedures } \\
\text { - Contextual use of art terminology } \\
\text { - Transfer leaming }\end{array}$ & 15 & & & & . \\
\hline TOTAL & 50 & & & & \\
\hline
\end{tabular}

KEY: 1. no reflective evidence

2. little reflection

3. adequate reflection

4. above adequate reflection

5. very reflective

N.B.: Tick $\sqrt{ }$ in appropriate box.
Intemal/Extemal Assessor

….......

Date:

\section{Recommendation 2}

Because of practical constraints, lecturers and assessors are likely to encounter difficulties in interviewing each and every candidate being presented. The study therefore recommends that the student himself provides a summative self assessment of his own reflective capabilities for the external assessor to reflect upon. This involves asking the student a series of questions that attempt to assess the 
student's ability to reflect on his art-making processes, mastered competencies, inspirational sources, etc.

The following are possible question that can be asked and the written responses are then made part of the final submission together with the artist's statement. The questions are just a guide. Questions can be adapted according to limitations, capabilities and contexts of individual colleges.

1. Describe and explain your artistic style.

2. Comment on your personal approach to media handling and use of art elements and principles of design.

3. What successes did you achieve during the course of studio production?

4. What major failures and frustration did you encounter and how do you intend to overcome these in future?

5. What artistic direction do you intend to follow basing on your achievements and failures?

\section{Conclusion}

After reviewing and putting into practice the notion of reflection in art and design, it is important that the study concludes by re-emphasising this critical role. Scott Grosh (as cited in Winner \& Simmons, 1992: 21), an art teacher, once said:

In all the forms of reflection that we have worked with, the important element that has to be present is a kind of dialogue, an exchange of ideas ... Students may not initially know how to engage in this reflective kind of process. They need to have the opportunity to see a model of the process working, to share ideas with other students before they are asked to give more private, personal written responses. For that reason, I use informal class dialogue to introduce reflective thinking. It provides students with public examples of how to proceed; it provides them with multiple points of view ... It can be done spontaneously; it can be done when and where needed; it can be done briefly ... You have the opportunity to ask another question; you can respond immediately to students.

\section{References}

Abraham, R. (2002). Art education in Zimbabwe. The International Jaurnal of Art and Design Education, 21(2), 116-123. 
Bartet, M. (1990). Guidelines for evaluation and assessment in art and design education 5-18 years. Joumal of Art and Design Education, 9(3), 299-313.

Bogdan, R.C.; \& Biklen, S.K. (1992). Qualitative Research for Education. An Introduction to Theory and Methods (2nd Ed.). Boston: Allyn and Bacon.

Castiglione, L.V. (1996). Portfolio assessment in art education. Arts Education Policy Review, 97(4), 2-9.

Cart, W.; \& Kernmis, S. (1986). Becoming Critical, Knowledge and Action Research. Lewes: The Falmer Press.

Centra, J.A. (1994). The use of the teaching portfolio and student evaluations for summative evaluation. Joumal of Higher Education, 65(5), 555-570.

Cho, M. (1999). Portfolio Development in a Secondary Teaching Credential Progtamme. National Society for Education in Art and Design (NSEAD): 207-212.

Coleman, H.L.K (1996). Portfolio assessment of multicultural counselling competency. The Counselling Psychologist, 24(2), 216-229.

Elliot, J. (1991). Action Research For Educational Change. Buckingham: Open University Press.

Guba, E.G.; \& Lincoln, Y.S. (1989). Fourth Generation Evaluation. Newbury Park, CA: Sage.

Hamblen, K.A. (1987). An examination of discipline based art education issües. $A$ Journal of Issues and Research in. Ant Education, 28(2), 68-78.

Hamilton, M.L. (Ed.). (1998). Reconceptualising Teaching Practice: Self-study Teacher Education. London: Falmer Press.

Kemmi, S.; \& Taggart, R (Eds.) (1982). The Action Research Reader. Geelong, Victoria, Australia: Daekin University Press. 
Mamvuto; A. (2002). Involving students in the evaluation process of their own creative art studio productions through mutual evaluation. The Zimbabwe Bulletin of Teacher Education, 11(2), 1-14.

Marshall, C.; \& Rossman; G.B. (1999). Designing Qualitative Research (3rd ed.). London: Sage Publications Ltd.

Mckeman, J. (1991). Cumiculum Action Researich. A Handbook of Methods and Resources for - the Reflective Practioner. London: Routledge \& Kegan Paul.

Miller, J.L. (1990). Creating Spaces and Finding Voices: Teachers Collaborating for Empoiverment. Albany: State University of New York.

Mouton, J.; \& Marais, H.C. (1990). Basic Concepts in the Methodology of the Social Sciences. Pretoria: Human Sciences Research Council (HSRC) Publishers: - -

Paulson, F.L.; Paulson, P.R; \& Meyer, C.A. (1991). What makes a portfolio a portfolio. Educational Leadership, 48(5), 60-63.

Prentice, R. (1995). Teaching Art and Design: Addressing Issues and Identifying Directions. - London: Casell Education.

Stout C.J. (1995).Critical conversations about art: A Description of higher order thinking generated through the study of art criticism. A Joumal of Issues and Research, 36(3), 170-188.

Thistlewood, D. (1993). Curricular development in critical studies. Joumal of Art and Design Education, 12(3), 105-113.

Tierney, R.C.; Carter, M.A.; \& Desai, L.E. (1991). Portfolios in Reading-Writing Classroom. Norwood: MA Christopher-Gordon.

University of Zimbabwe Board of Studies. (1996). Policy Guidelines on Associate, Affiliate Status and Special Relationship with the University of Zimbabuve (UZ) Including Teaching Hospitals ASTC/23/96. Harare: University of Zimbabwe, 
Winner, E.; \& Simmons, S. (1992). Arts Propel: A Handbook for Visual Arts. Pittsburgh: Educational Testing Services. 


\section{(c) (1) (9)}

This work is licensed under a

Creative Commons

Attribution - NonCommercial - NoDerivs 3.0 License.

To view a copy of the license please see:

http://creativecommons.ora/licenses/bv-nc-nd/3.0/ 